\title{
Group Farming -Sustainable Way of Livelihood
}

\section{Sreeni KR*}

Amria SeRVe, Amrita Vishwa Vidyapeetham Amritapuri Campus, Kerala, India

*Corresponding Author: Sreeni KR, Amria SeRVe, Amrita Vishwa Vidyapeetham Amritapuri Campus, Kerala, India.

Received: May 03, 2019; Published: July 31, 2019

DOI: 10.31080/ASAG.2019.03.0592

\section{Abstract}

The study was carried out in Sadivayail Village, Mathuvarayapuram Panchayath, Thondamuthur Block Coimbatore District, to know how group farming helps farmers to make a sustainable income from rice and assess the relationship between adoption level and switch on to organic farming. By 2012 most of the farmers left farming due to lack of rain, cost of seed, fertilizer, pesticide and low market price. On 09 May 2016, a resolution was passed at the village level where 20 (most of the families consist of 4 or 5 members) such most deprived families of the village were selected to start group farming and started an bank account under Canara Bank Alandurai under the name of Amrita Vyavasayam Kulu. Together they defined the responsibilities and formulated guidelines for internal management.

A sample of ninety five farmers was selected from Sadivaiyal, a tribal hamlet in the Boluvampatti forest range using random sampling method (each member of the population has an equal chance of being selected as subject). The data was collected using Participatory Rural Appraisal (PRA) methods such as group interviews, discussions and activities transect walks, and livelihood analysis. The collected data was analysed with statistic tools. Twelve independent variables viz Education Level, Occupation, Annual Income, Farm Size, Experience in Paddy Cultivation, Undergone Training, Credit, Livestock Values, Marketing Knowledge, Awareness on Post Harvesting, Social Participation, ITC Usage Tools and Production (Tons) and adoption level of paddy farmers as dependent variable (age) were selected for the study. The data were collected with the help of a well-structured and pre-tested interview schedule. The collected data were analyzed with suitable statistical tools.

After all PRA exercises, open discussions and interviews, farmers began their organic rice production activities on June 20 th 2016. The initiative used at Sadivayail village for 140 days a blend of both traditional and modern technology, group farming and convergence methods for manure and pesticide application, innovation, and even banking were shown step by step in methodology.

Keywords: Organic Farming; Convergence Method; Tribal Hamlet; Bhavani Rice; Organic Rice Production; Panchagavya; Jivamritham; Mulching

\section{Introduction}

It investigated the farming practices of small and marginal farmers involved in organic rice production with the support of Amrita SeRVe. The project was started on May 2016. It is an NGO which plays important roles from organizing the farmers in groups, opening bank accounts, purchasing seeds, supports capacity building and finally to branding and marketing. The study of farming practices shows that rice production by small and marginal farmers individually in Sadivaiyal is not profitable by conventional practices. Therefore, most of the farmers had stopped farming. The wellknown rice-plots became corridors for wild animals like elephants, wild boars and bears, monkey and peacock.

In the absence of irrigation facilities, farmers primarily depended on rain-fed agriculture. Owing to water scarcity, annual rice cultivation became a non-profitable activity. Hence they had stopped 
farming for the past three years, and had resorted to daily-wage labour in the forest vicinity, for their livelihood. Consequently, many farmers were in the grip of heavy debts which they owed to the rural moneylenders.

Amrita Sadivaiyal Vyavasaya Kulu (Amrita Sadivaiyal Farmers Club), a participatory system of farmers interested in organic farming was constituted. Twenty members made an initial contribution of Rs.500 each, and opened a joint bank account in Canara Bank, Alandurai. Organic agriculture was undertaken on thirty-five acres of agricultural land and then extended to fourty acres of land.

The Convergence Method of Farming drastically cut the entire cultivation costs, which resulted in substantially higher profits.

\section{Methodology}

Step by step

\section{Farmer's Club and Bank Account}

On 09 May 2016, a resolution was passed at the village level where twenty of the most deprived families of the village were selected to start group farming. First step was forming a farmer's club which was named Amrita Sadivayail Vyavasaya Kulu (Amrita Sadivayail Farmers Club). Each of the twenty members initially contributed Rs 500, and with the help of Amrita SeRVe they opened a bank account at Canara Bank Alandurai under the name of Amrita Vyavasayam Kulu. The total land holdings of land were thirtyfive acres and all twenty farmers decided to do organic. The Amrita SeRVe team worked with the farmers to address their need for selfdetermination and ownership, and together they defined the responsibilities and formulated guidelines for internal management.

\section{Collaboration and convergence}

Amrita SeRVe played an important role in organizing the farmers into groups and guiding them in the proper direction, starting with activities like the selection and purchasing of seed, soil testing, organizing tractors for primary and secondary tilting, crop planning, water budgeting \& water conservation measures, setting up technical training opportunities, giving support in capacity building, and finally branding and marketing.

\section{Repair all existing irrigation System}

The agriculture is primarily rain-fed, while the irrigation is completely dependent upon water from the main stream. Mud bunds built by the farmers help channelize water from the natural stream for irrigation. This water is diverted to a couple of nearby villages and hence is insufficient for irrigation. In spite of a proper water budgeting system in Sadivaiyal, still there is a shortage of water for paddy cultivation in the 40 acres of land.

\section{Selection of seeds}

The production and use of Bhavani rice has been on the decline over the last 10 years, however it was once a staple food of the Sadivayail village as well as Tamil Nadu. The farmers suggested they prefer to grow Bhavani because of its taste, reasonable price and nutritional value. It is also in high demand among the Flattened rice (also called beaten rice) and Aval or Poha making industries. The potential for by-product sales also increases as its hay (or straw) are also in high demand among farmers and mushroom growers. With this, the initiative is also trying to bring about good health habits and generate a traditional seed bank for Bhavani rice.

\section{Pre-Harvesting}

This section of farming is highly labour intensive and time consuming. The step includes many processes like transplantation, regular weeding, irrigation and maintenance of the crop till the harvest. The farmer controls the expenses of both outsourcing and convergence methods in the pre-harvesting phase.

\section{Compost pits}

Eight organic pits were prepared of dimension 7X7 ft 60 days before tilling the land. The pit was filled with crop residue, animal wastes, food garbage, cow-dung, and different leaves available in forest area which easily undergoes composting.

\section{Side protection}

Infrastructure support to paddy cultivation includes strengthening and repairing of natural bunds which exist from the past ten years. They help channelize the water to reach the proper destinations without loss at any stage. It also helps to increase the ground water level because the excess water seeps through the soil. Figure Side Protection.

\section{Mulching}

The top soil was covered with plant material such as leaves, grass, herbs etc. Mulching enhances the activity of soil organisms such as earthworms. It helps prepare the soil structure in such a way that plenty of small and large pores are created through which rainwater can easily infiltrate the soil, thus reducing surface runoff. 
Primary tillage

Primary tillage is usually the first soil ploughing after the last harvest. It is done to attain depths of soft soil with varying clod sizes. It also kills weeds by burring or cutting and exposing roots to the soil. A cultivator/tiller is attached to the tractor and run through the field.

\section{Secondary tillage}

Secondary Tillage is to improve the seedbed by increased soil pulverization, to conserve moisture through destruction of weeds, and to cut up crop residues by using various types of harrows, rollers or pulverizers, and tools for mulching and fallowing.

A tiller is small piece of equipment used with a tractor engine that is commonly operated for preparing the soil for seed beds. Seed beds are a small raised platform of land in which the seed are first grown then transplanted to the main fields. Describes the expenses of both outsourcing and convergence methods in tiller use.

\section{Capacity building on organic manure}

From the very onset Amrita SeRVe trained the farmers in preparing organic manures like Beejamrutham, Jeevamrutham, Panchanmritam and other organic pesticides.

Preparation of jeevamrutham and beejamrutham

Beejamrutham

Take 20 liter Water, 5 Kg Local Cow Dung, 5 liter Local Cow Urine, 50 Gram Lime \& Handful soil from the bund of the farm. Then next morning, squeeze this bundle of the cow dung in that water thrice continuously, so that all essence of cow dung will accumulate in that water.

Beejamrutham on the spread seeds of any crops, treat these seeds well by hands, dry it well and use for sowing. It helps to stop fungus and for the plant growth. The beneficial microorganisms present in beejamrutha are known to protect the crop from harmful soil-borne and seed-borne pathogens.

Jeevamrutham was prepared at the farm by taking 50 liter water in barrel and add $5 \mathrm{~kg}$ cow dung plus 5 litre in cow urine and then Mix well with the help of wooden stick add two kg jaggery and two kf of gram or any pulse flour mix this solution well with wooden stick. Keep this solution for fermentation for 5 to 7 day and mix 3 times daily. Shake the solution regularly three times a day.
Used as soil application either by sprinkling or by applying through irrigation water.

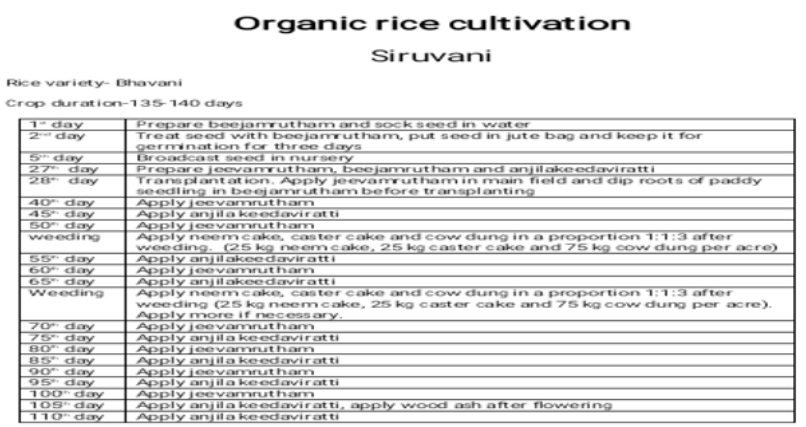

Figure 1

\section{Pest control}

The objective of natural pest control is to restore the balance between the 'pest and predator' by keeping the pests and diseases down to an acceptable level. The aim is not to eradicate them altogether, as they also have a role to play in the natural system. Anjilakeedaviratti is a pest control made of five sap-leaves and soaked (for $48 \mathrm{hrs}$ ) in water (10lts) and cow urine (5lts). Another pest control is a home-made mixture of tobacco leaves mixed in water (10lts) and cow urine (5lts). Green chilly (100gms) mixed with cow urine (5lts) was applied at different stages of growth. Such environment-friendly measures help protect the flora and fauna of the forests. They also reduced the costs from Rs.10,000 to Rs.2000 per acre.

\section{Post-Harvesting}

Post-harvesting includes getting final products from the harvested crop. Especially for rice, the choice of the product decides the expenses. Major products for paddy crop are paddy as seeds, rice (husk removed).

\section{Parboiling and milling}

The main process in post harvesting is harvesting the crop. In the outsourcing method, labour for harvesting cost about Rs.10000.00; however as the people in convergence method are of the same village, that cost is halved to only Rs.5000.00. But using machine it cost Rs 3120 Rs so we have chosen the technology for post harvesting. Other processes like sacking, parboiling and mill- 
ing also include in the step of post-harvesting however these costs are not included in this analysis. After each step of processing, the value of the rice increases, thus the income covers expenses and, in many cases,, gives profit.

Returns from organic bhavani rice production

When the crop was harvested in 2017-18, the total yield from the 40 acres was 36,120 kg. On average, farmers produced 1032 kg per acre and sold it for Rs. 28.00 per kg, resulting in an average return per acre of Rs. 28896 and also return from straw is Rs 24000, As most of the farmers who has one acre, the average return for each producer was Rs. 52896. With this substantial return, the farmers were able to pay off their outstanding debts. Thus it gives us the conclusion that convergence group method of farming is more preferred over individual farming and while this paper only covers the activities of the first year, the results suggest a promising future.

\section{Results and Discussion}

It could be observed from Table 1 that majority of the farmers doing rice belonged to old age category (above 45) of 44.44 percentages from last three years. The middle age group (between 31 to 45 ) prefers doing farming and labour jobs nearby villages. Most of the youngsters prefer only regular job with reasonable monthly salary than doing farming even though they have their own lands but support parents during farming activities. Nearly half of the respondents $(68 \%)$ were Illiterate or partially literate (only know how to write names). Most of the villages in the study area were having education facilities upto primary school level then they have to go nearby towns for higher studies. They have not much interest in the present class room education system as they all belong to Irrula community, ST and their livelihood are forest and forest produce [1-5].

\begin{tabular}{|c|c|c|c|c|c|c|c|c|c|c|c|}
\hline \multicolumn{12}{|c|}{ Distribution of Farmers based on their Profile } \\
\hline & & & Number & \multicolumn{2}{|c|}{ Percentage } & \multirow{2}{*}{\multicolumn{2}{|c|}{\begin{tabular}{|c|c|} 
Number & Per \\
Years
\end{tabular}}} & Percentage & \multirow{2}{*}{\multicolumn{2}{|c|}{\begin{tabular}{c|c} 
Number & $P e$ \\
Years
\end{tabular}}} & Percentage \\
\hline & & & \multicolumn{2}{|c|}{ Years } & \multirow{2}{*}{$\%$} & & & & & & $\%$ \\
\hline SLNO & Age (X) & Education Level (Y1) & 2015-2 & 16 & & \multicolumn{2}{|c|}{ 2016-2017 } & $\%$ & \multicolumn{2}{|c|}{ 2017- 2018} & \\
\hline \multirow[t]{4}{*}{1} & Old Age (above 45) & Illiterate & 40 & 35 & 36.84 & 40 & 35 & 36.84 & 40 & 35 & 36.84 \\
\hline & $\begin{array}{l}\text { Middle Age (31 to } \\
45)\end{array}$ & Functionally Literate & 30 & 30 & 31.58 & 30 & 30 & 31.58 & 30 & 30 & 31.58 \\
\hline & $\begin{array}{l}\text { Youth (between } 20 \\
\text { to } 30 \text { ) }\end{array}$ & High School (I-X)) & 25 & 25 & 26.32 & 25 & 25 & 26.32 & 25 & 25 & 26.32 \\
\hline & Total & & 95 & 90 & 94.74 & 95 & 90 & 94.74 & 95 & 90 & 94.74 \\
\hline \multirow[t]{5}{*}{2} & Age $(X)$ & Occupation (Y2) & & & & & & & & & \\
\hline & Old Age (about 45) & Farming Alone & 40 & 40 & 42.11 & 40 & 40 & 42.11 & 40 & 40 & 44.44 \\
\hline & $\begin{array}{l}\text { Middle Age (31 to } \\
45)\end{array}$ & Farming + Labour & 30 & 25 & 26.32 & 30 & 25 & 26.32 & 30 & 30 & 33.33 \\
\hline & $\begin{array}{l}\text { Youth (between } 20 \\
\text { to } 30 \text { ) }\end{array}$ & $\begin{array}{l}\text { Farming + other Jobs } \\
\text { (Security/Sales Boy/ } \\
\text { Plumber/Electrician/ } \\
\text { Mechanic/Hotels) }\end{array}$ & 25 & 12 & 12.63 & 25 & 16 & 16.84 & 25 & 20 & 22.22 \\
\hline & Total & & 95 & 77 & 81.05 & 95 & 81 & 85.26 & 95 & 90 & 100.00 \\
\hline \multirow[t]{5}{*}{3} & Age $(\mathrm{X})$ & Annual Income(Y3) & & & & & & & & & \\
\hline & Old Age (about 45) & Below 100000 & 40 & 40 & 42.11 & 40 & 10 & 10.53 & 40 & 20 & 21.05 \\
\hline & $\begin{array}{l}\text { Middle Age (31 to } \\
45)\end{array}$ & $\begin{array}{l}\text { Between } 100000- \\
200000\end{array}$ & 30 & 2 & 2.11 & 30 & 20 & 21.05 & 30 & 25 & 26.32 \\
\hline & $\begin{array}{c}\text { Youth (between } 20 \\
\text { to } 30 \text { ) }\end{array}$ & Above 200000 & 25 & 0 & 0.00 & 25 & 2 & 2.11 & 25 & 4 & 4.21 \\
\hline & Total & & 95 & 42 & 44.21 & 95 & 32 & 33.68 & 95 & 49 & 51.58 \\
\hline
\end{tabular}




\begin{tabular}{|c|c|c|c|c|c|c|c|c|c|c|c|}
\hline \multirow[t]{5}{*}{4} & Age $(X)$ & $\begin{array}{c}\text { Farm Size (in Hectares) } \\
(\mathrm{Y} 4)\end{array}$ & & & & & & & & & \\
\hline & Old Age (about 45) & $\begin{array}{c}\text { Margin (below } 2 \\
\text { Hectare) }\end{array}$ & 40 & 40 & 42.11 & 40 & 40 & 42.11 & 40 & 40 & 42.11 \\
\hline & $\begin{array}{l}\text { Middle Age (31 to } \\
45)\end{array}$ & $\begin{array}{c}\text { Small (B/W } 2 \text { and } 4 \\
\text { Hectare) }\end{array}$ & 30 & 2 & 2.11 & 30 & 2 & 2.11 & 30 & 2 & 2.11 \\
\hline & $\begin{array}{c}\text { Youth (between } 20 \\
\text { to } 30 \text { ) }\end{array}$ & Large & 25 & 0 & 0.00 & 25 & 0 & 0.00 & 25 & 0 & 0.00 \\
\hline & Total & & 95 & 42 & 44.21 & 95 & 42 & 44.21 & 95 & 42 & 44.21 \\
\hline \multirow[t]{5}{*}{5} & Age $(X)$ & $\begin{array}{c}\text { Experience in Paddy } \\
\text { Cultivation (Y5) }\end{array}$ & & & & & & & & & \\
\hline & Old Age (about 45) & $\begin{array}{c}\text { Left in Between and } \\
\text { resumed }\end{array}$ & 40 & 3 & 3.158 & 40 & 40 & 42.11 & 40 & 40 & 42.11 \\
\hline & $\begin{array}{l}\text { Middle Age (31 to } \\
45)\end{array}$ & $\begin{array}{c}\text { Left in Between and } \\
\text { resumed }\end{array}$ & 30 & 0 & 0.000 & 30 & 30 & 31.58 & 30 & 30 & 31.58 \\
\hline & $\begin{array}{c}\text { Youth (between } 20 \\
\text { to } 30 \text { ) }\end{array}$ & $\begin{array}{l}\text { Left in Between and } \\
\text { resumed }\end{array}$ & 25 & 0 & 0.000 & 25 & 15 & 15.79 & 25 & 20 & 21.05 \\
\hline & Total & & 95 & 3 & 3.158 & 95 & 85 & 89.47 & 95 & 90 & 94.74 \\
\hline \multirow[t]{5}{*}{6} & Age $(X)$ & $\begin{array}{c}\text { Undergone Training } \\
\text { (Y6) }\end{array}$ & & & & & & & & & \\
\hline & Old Age (about 45) & Attended once Recently & 40 & 5 & 5.26 & 40 & 35 & 36.84 & 40 & 38 & 40 \\
\hline & $\begin{array}{l}\text { Middle Age (31 to } \\
45)\end{array}$ & Attended once Recently & 30 & 3 & 3.16 & 30 & 22 & 23.16 & 30 & 28 & 29.47 \\
\hline & $\begin{array}{c}\text { Youth (between } 20 \\
\text { to } 30 \text { ) }\end{array}$ & Attended once Recently & 25 & 0 & 0.00 & 25 & 16 & 16.84 & 25 & 22 & 23.16 \\
\hline & Total & & 95 & 8 & 8.42 & 95 & 73 & 76.84 & 95 & 88 & 92.63 \\
\hline \multirow[t]{5}{*}{7} & Age $(X)$ & Credit (Y7) & & & & & & & & & \\
\hline & Old Age (about 45) & Nationalized Bank & 40 & 2 & 2.11 & 40 & 30 & 31.58 & 40 & 10 & 10.53 \\
\hline & $\begin{array}{l}\text { Middle Age (31 to } \\
45)\end{array}$ & Cooperative Bank & 30 & 2 & 2.11 & 30 & 15 & 15.79 & 30 & 5 & 5.26 \\
\hline & $\begin{array}{c}\text { Youth (between } 20 \\
\text { to } 30 \text { ) }\end{array}$ & Money Lender & 25 & 20 & 21.05 & 25 & 0 & 0.00 & 25 & 0 & 0.00 \\
\hline & Total & & 95 & 24 & 25.26 & 95 & 45 & 47.37 & 95 & 15 & 15.79 \\
\hline \multirow[t]{5}{*}{8} & Age $(X)$ & Livestock Values (Y8) & & & & & & & & & \\
\hline & Old Age (about 45) & Goat & 40 & 10 & 10 & 40 & 50 & 50 & 40 & 80 & 80 \\
\hline & $\begin{array}{l}\text { Middle Age (31 to } \\
45)\end{array}$ & Cow & 30 & 3 & 3 & 30 & 8 & 8 & 30 & 10 & 10 \\
\hline & $\begin{array}{l}\text { Youth (between } 20 \\
\text { to } 30 \text { ) }\end{array}$ & others & 25 & 0 & 0 & 25 & 20 & 20 & 25 & 50 & 50 \\
\hline & Total & & 95 & 13 & 13 & 95 & 78 & 78 & 95 & 140 & 140 \\
\hline 9 & Age $(X)$ & $\begin{array}{l}\text { Marketing Knowledge } \\
\text { (Y9) }\end{array}$ & & & & & & & & & \\
\hline
\end{tabular}




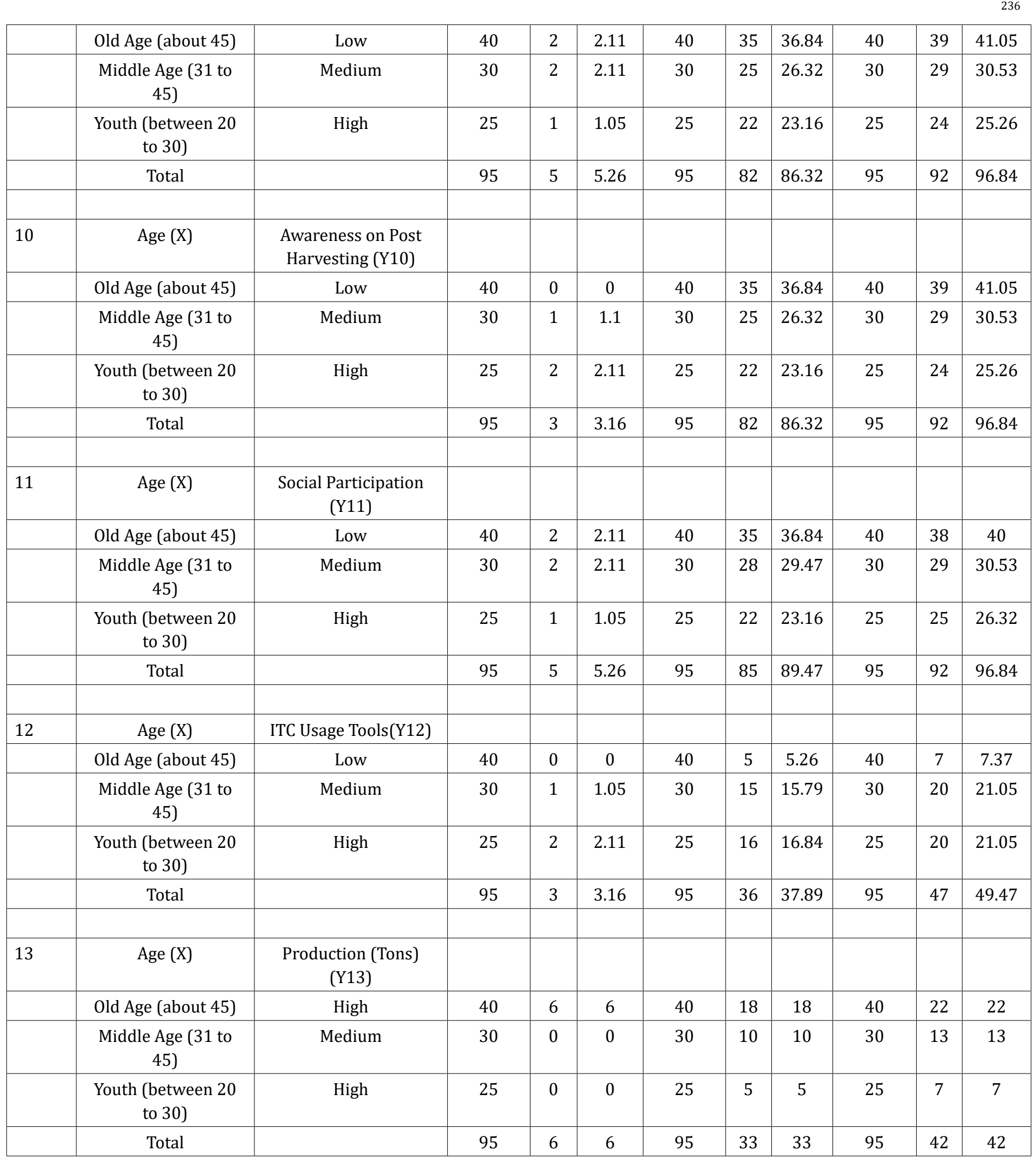

Table 1: Yield and yield attributing parameters for Bhavani rice in relation to different Parameters from 2016-2018 at Sadivayail Village. 
The findings are in line with the findings of Mrs Ramya who also reported that majority of the farmers was illiterates. All of them $(100 \%)$ of the respondents had farming alone as their occupation. Majority (81\%) of the respondent's income category was below Rs one lakh in the year 2015-16 when project implemented. By 2012 almost all farmers left farming due to lack of water, disorganized farming, increasing price of fertilizer, pesticide and market price. After started group farming at sadivayail by forming farmers club using convergence method farmer's income gradually increased from Rs 50000/yearly and by 2018 their income in between one lakh and 2 lakh. After proper training and guidance they are promoting organic farming. Apart from that respondent's basic urge to earn more and their desire to improve their standard of living to clear old debts and to fulfill family commitments, low to medium high level of educational status, social participation and mass media exposure were some of the reasons.

The reason might be planning agriculture activities in group from selection of seed (Bhavani rice), preparation of fertilizer and pesticide organically and exchange of labours and cut down of all initial costs, and also return of good yields and using marketing network of organic rice in study area. Most (90\%) of the respondents' were marginal farmers. The reasons were the study area comes under rained area which could have made the farmers not to opt second crop.

Most of the respondents (100\%) left in between and resumed cultivation due to lack of water, non profitable, lack of guidance, lack of farming practices, technologies and animals attack. By 2018 majority of the respondents had attended training program once (100\%), social participation became high and exposure to ITC tools became medium respectively. The market knowledge were increased from low high (96.84\%). The reason might be regular visits made by the Amrita SeRVe staff and provide all necessary support from seed, training, pre and post harvesting techniques, training on various preparations of organic fertilizer and pesticides and marketing support.

Amrita Vivasayam Kulu, Sadivayail (Farmers Group)) of the respondents had attended few training programs on organic farm- ing once $(100 \%)$ and now are in a position to train other farmers. Majority of the respondents had high level of credit orientation during 2015 -16 and taken from money lenders (25.26\%) and by 2018 the credit level decrease by (15.79\%) and now taking from nationalized bank and cooperative banks and rest of farmers without credit.

After forming farmers group in 2016 and when first crop harvested the farmers closed all the loans taken from money lenders and freed them from moneylender clutch. The average profit from one acre land was 60,000 Rs. It also helps to improve the living standard and ensure food security in villages.

From Table 2, it could be inferred that out of thirteen depended variables on studied, eight variables namely,, Occupation(Y2), Annual Income(Y3), Experience in Paddy Cultivation (Y5), Undergone Training (Y6), Marketing Knowledge (Y9), Awareness of Post Harvesting Technology (Y10), Social Participation (Y11) and Production (Tons) (Y13) showing significant and positive growth from Year 2016-16 to 2017-18. The variable (Y3) and Production (Y13) show significant growth in all age groups from Year 2016-16 to 2017-18. The variable (X7) depended on Variable X show drastic change where farmers changed the credit behavior from money lender to Nationalized or Cooperative banks. The variable Livestock (Y8) and Production also showing positive trend and are mutually benefited. The Variable (Y2) and (Y3) show positive trend and both job creation and income became double by the year 2017-18. The variable (Y1) Education and (Y4) the land size doesn't bring much significant changes in the years because the number of farmers in age groups above 45 years were higher and land size remain fixed.

Pearson's correlation coefficient

$$
r=\frac{n\left(\sum x y\right)-\left(\sum x\right)\left(\sum y\right)}{\sqrt{\left[n \sum x^{2}-\left(\sum x\right)^{2}\right]\left[n \sum y^{2}-\left(\sum y\right)^{2}\right]}}
$$

Figure 2 


\begin{tabular}{|c|c|c|c|c|c|c|c|c|c|c|c|c|c|c|}
\hline \multirow[t]{2}{*}{ Year } & \multirow{2}{*}{$\begin{array}{c}\begin{array}{c}\text { Fixed } \\
\text { Variable }\end{array} \\
\text { Age }\end{array}$} & \multicolumn{13}{|c|}{ Depended Variables } \\
\hline & & $\begin{array}{l}\text { Educa- } \\
\text { tion } \\
\text { Level }\end{array}$ & $\begin{array}{l}\text { Occu- } \\
\text { pation }\end{array}$ & $\begin{array}{l}\text { Annual } \\
\text { Income }\end{array}$ & 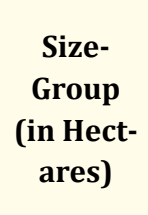 & $\begin{array}{l}\text { Experi- } \\
\text { ence in } \\
\text { Paddy } \\
\text { Cultiva- } \\
\text { tion }\end{array}$ & $\begin{array}{c}\text { Under- } \\
\text { gone } \\
\text { Training }\end{array}$ & Credit & $\begin{array}{c}\text { Live- } \\
\text { stock } \\
\text { Values }\end{array}$ & $\begin{array}{c}\text { Mar- } \\
\text { keting } \\
\text { Knowl- } \\
\text { edge }\end{array}$ & $\begin{array}{c}\text { Awareness } \\
\text { of Post } \\
\text { Harvesting } \\
\text { Technology }\end{array}$ & $\begin{array}{c}\text { Social } \\
\text { Partici- } \\
\text { pation }\end{array}$ & $\begin{array}{c}\text { ITC } \\
\text { Usage } \\
\text { Tools }\end{array}$ & $\begin{array}{l}\text { Produc- } \\
\text { tion } \\
\text { (Tons) }\end{array}$ \\
\hline & 1 & 2 & 3 & 4 & 5 & 6 & 7 & 8 & 9 & 10 & 11 & 12 & 13 & 14 \\
\hline & $\mathrm{x}$ & Y1 & Y2 & Y3 & Y4 & Y5 & Y6 & Y7 & Y8 & Y9 & Y10 & Y11 & Y12 & Y13 \\
\hline $2015-16$ & $\begin{array}{c}\text { Old Age } \\
\text { (above 45) }\end{array}$ & 0.84 & 0.5 & -0.19 & 0.96 & 0.94 & 0.95 & -0.76 & 13 & 0.76 & -0.98 & 0.76 & -0.98 & 6.00 \\
\hline $2016-17$ & $\begin{array}{l}\text { Middle Age } \\
\text { (31 to } 45 \text { ) }\end{array}$ & 0.84 & 1.00 & 0.27 & 0.96 & 0.95 & 1.00 & 0.98 & 78 & 0.99 & 0.99 & 0.99 & -0.97 & 33.00 \\
\hline $2017-18$ & $\begin{array}{l}\text { Youth } \\
\text { (between } \\
20 \text { to } 30 \text { ) }\end{array}$ & 0.84 & 1.00 & 0.59 & 0.96 & 0.98 & 1.00 & 0.98 & 140 & 1.00 & 1.00 & 1.00 & -0.94 & 36.00 \\
\hline
\end{tabular}

Table 2: Variables.

The Pearson's correlation equation was fitted for adoption level of the respondents and is given below.

It could be seen from the equation that the Correlation Cofficent $[\mathrm{r}]$ of variables educational status (X2), Occupation (Y2), Annual Income (Y3), Experience in Paddy Cultivation (Y5), Undergone Training (Y6), Marketing Knowledge (Y9), Awareness of Post Harvesting Technology (Y10), Social Participation (Y11) and Production (Tons) (Y13) would also increase adoption level of paddy farmers on recommended rice cultivation

\section{Impact}

The project is continuing from last three years and its mean of livelihood and way to end poverty and hanger at villages and find new job opportunities at rural India. The impacts of project were nearly five of hamlet adopted Bhavani rice and around 150 acres of land converted to Bhavani in last three years.

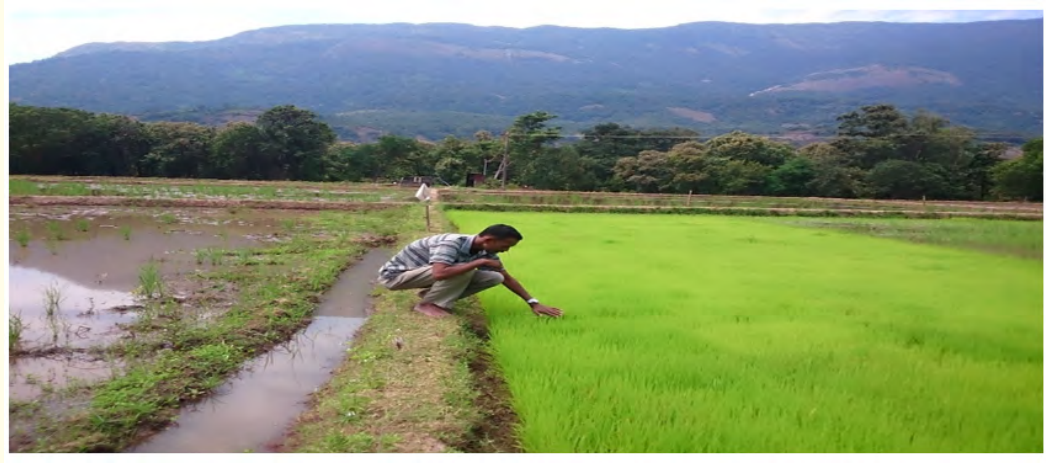

Figure 3 


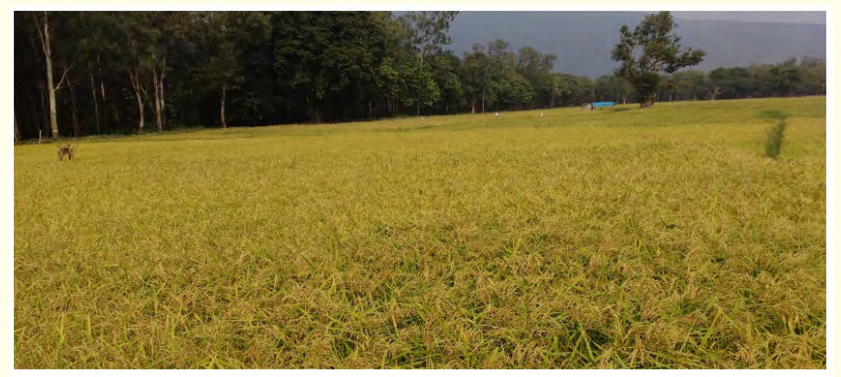

Figure 4

\section{Bibliography}

1. Chambers R. "Origins and practice of Participatory Rural Appraisal”. World Development 22.7 (1994): 953-969.

2. Galeski B. "The models of collective farming', In: Cooperative and commune: group farming in the economic development of agriculture". Edited by P. Dorner (1987): 17-42, New York: University of Wisconsin Press.

3. Ministry of Rural Development (MRD). Report on Convergence Initiatives in India An Overview, Ministry of Rural Development Government of India, New Delhi (2010).

4. Olatunji O and Letsoalo S. "Value congruence, the success of group farming in agricultural extension". South African Journal of Agricultural Extension 4.1 (2013): 26-33.

5. Ramanjaneyulu G. Agrarian Crisis in India, Centre for Sustainable Agriculture (CSA), Hyderabad, India (2015).

\section{Volume 3 Issue 8 August 2019}

(C) All rights are reserved by Sreeni KR. 